\title{
Rejecting Unreasonable Sexual Expectations: Limits on Using a Rape Victin's Sexual History to Show the Defendant's Mistaken Belief in Consent
}

\author{
Sakthi Murthy $\dagger$
}

Throughout history, our culture has made assumptions about people based on certain physical characteristics. Gender is one example, and the law of rape is one of the clearest illustrations. Rape laws assume that men act a certain way while women act quite differently. For example, evidence of a rape victim's past consensual sexual practices was long considered relevant. After reformers questioned the assumptions behind this use of evidence, many jurisdictions enacted rape shield laws which bar such evidence when offered to show that a rape victim consented. The purposes behind these rape shield laws, however, may be thwarted by the mistake of fact defense. This defense exonerates an attacker who reasonably believed that the victim consented to sex even if she did not, in fact, consent. A rape defendant may offer evidence that he knew the victim was "promiscuous" and then may argue that this led him mistakenly to believe that she consented. This Comment argues that evidence of a woman's sexual practices should be excluded in this situation. Believing that a woman consents to sex based on a mere perception of "promiscuity" is patently unreasonable. Reasonable behavior in a sexual context requires communication between partners, rather than reliance on stereotypes. The author explores the role of gender socialization in creating stereotypical views of male and female sexuality and argues that these harmful stereotypes should not be furthered by the justice system.

\section{INTRODUCTION}

It was Donald Robert Black's lucky night. He was about to meet a woman about whom he had heard promising things. Army inen joked regularly about their sexual encounters with her. He had even read one of the love letters she had written to another man. Although he had

$\dagger$ B.A. 1987, University of Toronto; J.D. candidate 1991, University of California, Berkeley. The author wishes to thank the niembers of the California Law Review and Professor Angela Harris. 
never met her, they had spoken on the telephone several times. He knew that she often came to the snack bar at the barracks to meet people. If the rest of the men had gotten their share, he expected to get his. It was going to be his lucky night.

Far from being lucky, Black's sexual encounter turned out to be a stroke of bad luck both for him and for rape law reformers. The rape case arising out of it, Doe v. United States, ${ }^{1}$ held that evidence of the victim's "promiscuity" was admissible to support the defendant's assertion that he reasonably but mistakenly beheved that the victim had consented to sex. ${ }^{2}$

The decision in Doe appears to contradict the language of Federal Rnle of Evidence 412, the "rape shield" statute. ${ }^{3}$ Lawinakers have recognized the low probative value of sexual history evidence and the high potential for prejudice when such evidence is admitted to show the victimi's consent. ${ }^{4}$ Congress and inany state legislatures have enacted evidentiary rules such as Rule 412,5 referred to as "rape shield" statutes. Under the typical rape shield statute, subject to certain exceptions, ${ }^{6}$ the defense may not introduce evidence of a rape victim's sexual history to prove that she consented to the sexual encounter in question. ${ }^{7}$

One factor complicating the operation of rape shield statutes is the apphication of the mistake of fact defense in rape cases. The inistake defense is not concerned with whether the woman actually consented. Rather, it allows the defendant to show that he believed that the woinan consented and thus that he lacked the requisite intent for rape.

In Doe, the defendant Black asserted that he was not guilty of a rape

1. 666 F.2d 43 (4th Cir. 1981). Doe originated in the Eastern District of Virginia. Federal jurisdiction was based on 18 U.S.C. $\$ 2242$ (1988), which concerns crimes occurring on military bases. The case was before the Fourth Circuit on an interlocutory appeal. The victim appealed rulings on the defendant's pretrial motion to admit evidence of the victim's past sexual behavior and on the victim's own civil action seeking permanent sealing of the record of the pretrial proceeding.

2. 666 F.2d at 48. But see People v. Guthreau, 102 Cal. App. 3d 436, 444, 162 Cal. Rptr. 376, 380 (1980) (evidence of victim's past sexual conduct with people other than the defendant was inadmissible to show the defendant's mistaken belief in eonsent); infra text accompanying notes 117 19 (discussing Guthreau).

3. FED. R. EVID. 412.

4. For a statistieal analysis of the prejudicial effect of sexual history evidence on jury verdicts, see H. FEILD \& L. BIENEN, JURORS AND RAPE 114-19 (1980). Judges may also hold stereotypieal views about sexuality which influence their decisions in rape cases. See infra note 51 and accompanying text.

5. For the text of the substantive portions of Rule 412 , see infra note 74 .

6. The two common exceptions are evidence of the victim's previous sexual activity with the defendant to show consent, see, e.g., FED. R. EvID. 412(b)(2)(B), and evidence of the victim's past sexual behavior with others, to prove whether the accused was the source of semen or injury, see, e.g., id. Rule 412(b)(2)(A).

7. See, e.g., id. Rule 412 . While rapists and rape victims may be of either gender, the overwhelming percentage of rapes concern male attackers and female victims. This Comment refers to rapists as males and rape victims as females. 
because he lacked the intent to have sex with the victim against her will. ${ }^{8}$ He sought to introduce evidence showing that the victim had a reputation for being sexually experienced, that he knew this, and that this knowledge led him reasonably to believe tliat she had consented to sex with him. ${ }^{9}$ The court admitted the evidence stating that, although not admissible to show consent, sexual history evidence may be admissible to show mistake. ${ }^{10}$

Doe is the only federal appellate case to address the use of sexual history evidence to support a mistake defense. The Doe court held that Congress did not intend the federal rape shield law to bar such evidence when offered by a rape defendant to support his claim of mistake of fact. ${ }^{11}$ Rather than approving the use of the evidence to show actual consent (as was the practice in pre-shield days), the Doe court allowed defense counsel to introduce the evidence to show its effect on the defendant's state of mind. ${ }^{12}$ Further, the Doe court found that evidence of the victim's sexual history was relevant to sliow a mistaken behief in consent that could be termed "reasonable."13 Thus, the mistake of fact defense provides a back door entrance for evidence of a rape victim's sexual history. ${ }^{14}$

This back door entrance presents a serious problem in the application of current rape shield statutes. Rape law reformers criticized preshield evidentiary laws for placing a rape victim "on trial" by allowing the defense freely to cross-examine the victim about her sexual history. ${ }^{15}$ These laws have, for the inost part, been rewritten in response to public pressure.

Application of the rape shield statutes, however, conflicts with aspects of the substantive law of rape. The mistake of fact defense, which

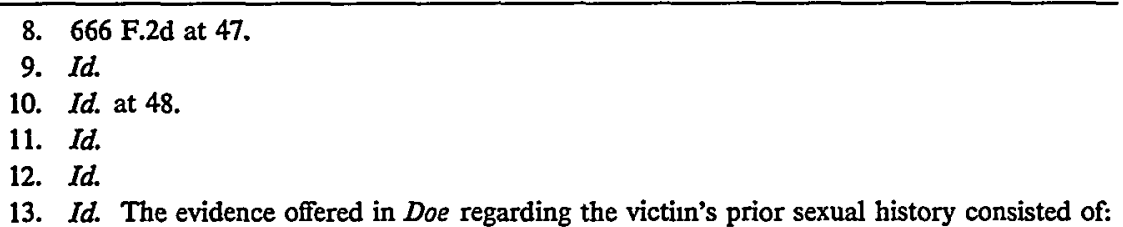

(1) evidence of the victim's general reputation around the defendant's Army post;

(2) evidence of the victin's habit of calling out to various soldiers in the barracks;

(3) evidence that the victim came to the barracks to ineet people;

(4) evidence from the victim's former landlord regarding her "promiscuity";

(5) evidence from a social worker about the victim's sexuality.

Id. at 47.

14. Courts and legislatures are beginning to grapple with the question of sexual history offered to support a mistake defense. For examples of recent legislative and judicial responses to the issue, see GA. CODE ANN. § 24-2-3 (1990) (recent statutory revision that strictly limits the circumstances under which sexual history evidence may be admitted to support a mistake defense); United States v. Saunders, 736 F. Supp. 698, 702, 705 (E.D. Va. 1990) (applying the rule in Doe, but concluding that sexual history is prejudicial and therefore imadnissible).

15. See, e.g., Estrich, Rape, 95 YALE L.J. 1087, 1094 (1986). 
potentially allows a rape defendant to go free after forcing sex on a woman because he thought she had consented, creates such a conflict. Most rape shield statutes do not exphicitly address the issue of admitting evidence of the victim's sexual history to support the defendant's mistaken belief in consent. The problem created by the interplay of rape shield laws and the mistake defense has not been widely discussed. ${ }^{16}$

This Comment addresses the following important question: Should evidence of a rape victim's "proimiscuity" be admitted to support the defense of imistaken belief in consent? The majority rule in the United States requires, quite correctly, that a imstaken behef in consent be both honest and reasonable to exonerate the defendant. ${ }^{17}$ Thus, the question becomes: Is it reasonable for a man to beheve that a woman consented to sex because he knew or behieved that she was sexually experienced?

This Comment argues that such a behef is normatively unreasonable. Sexual experience is not probative of whether a woman consented to sex on a particular occasion; a reasonable person infers consent based on communication during the encounter in question rather than on knowledge that a woman is sexually experienced. Evidence showing that a rape victim was sexually experienced is irrelevant to a defense of reasonable imstake and must be excluded by evidentiary rules barring irrelevant evidence. $^{18}$

This Comment is divided into four parts. En route to resolving the rape shield/mistake defense problem, Part I provides background for the substantive law of rape and examines the mistake defense. Part II covers the history and purpose of rape shield laws and surveys these laws in federal and state courts. Part III discusses cases in which sexual history evidence was offered to support a mistake defense. Part IV analyzes why a reasonable imistake as to consent cannot be based on knowledge that a woman is sexually experienced and explores situations where sexual history evidence could be relevant to a mistake defense.

\section{I}

The Substantive LaW of Rape: Actus Reus, MENS ReA, CONSENT, AND MistaKe

Rape was traditionally defined in terms of female consent, necessitating an iquiry into the victim's mental state rather than the mental

16. But see, e.g., Comment, Shifting the Communication Burden: A Meaningful Consent Standard in Rape, 6 HARv. WOMEN'S L.J. 143, 146-49 (1983) (criticizing the use of a reasonable person standard to evaluate mistake of fact). For a discussion of criminal intent and the mistake defense in general, see infra text accompanying notes $40-46$.

17. See infra notes $42-44$ and accompanying text.

18. See, e.g., FED. R. EVID. 402 ("Evidencc which is not relevant is not admissible."). 
state of her attacker. ${ }^{19}$ The mistake defense, if properly applied, alters the common law approach to rape by shifting the focus from the victim to the defendant. The inquiry becomes not whether the victim consented, but rather whether the defendant intended to have sex with a nonconsenting woman. Unfortunately, as this Part will show, the mistake defense has been used to preserve the traditional "victim as suspect" approach to rape by serving as a back door entrance for evidence of the victim's sexual history.

\section{A. The Development of the Traditional Consent Defense}

Most crimes are defined by an actus reus (guilty act) and a mens rea (guilty mind). ${ }^{20}$ The actus reus for rape has traditionally been the penile penetration of the vagina of a nonconsenting woman. ${ }^{21}$ The mens rea of rape has been less clear. While intent is usually recognized as an element of rape, some courts have actually suggested that there is no mens rea for rape and that a man should be strictly hable for nonconsensual intercourse. ${ }^{22}$

Rape historically has been treated differently from other crimes. Susan Estrich attributes this to the male-dominated justice system's suspicion of rape victims. ${ }^{23}$ Traditional rape trials engaged in the self-contradictory project of judging "the appropriateness of the woman's behavior, according to male standards of appropriate female behavior."24

Rape is not unique in requiring nonconsent, ${ }^{25}$ but its mordinate focus on consent distinguishes it from other areas of the criminal law. Consider the traditional test for nonconsent in rape cases-the resistance requirement. Historically, rape convictions were overturned if it were not proven that the victim had resisted throughout the act to the utmost

19. See Estrich, supra note 15 , at 1094.

20. W. LaFAve \& A. SCOTt, JR., Criminal LAW \& 3.1, at 193 (1986).

21. See S. Brownmiller, Against OUR WILl 424 (1975). Some states explicitly extend the definition of rape beyond penile penetration of the victim's vagina. See TEX. Penal Code ANN. $\$ 22.011$ (Vernon 1989). Section 22.011 reads:

(a) A person commits an offense if the person:

(1) intentionally or knowingly:

(A) causes the penetration of the anus or female sexual organ of another person who is not the spouse of the actor, by any means, without that person's consent.

22. See Katz, Expectation and Desire in the Law of Rape, 26 SAN Diego L. Rev. 21, 48 \& n.133 (1989) (lists cases where courts have suggested there is no mens rea for rape).

23. See Estrich, supra note 15, at 1094-95.

24. Id. at 1094. Deciding whether a rape actually occurred by how appropriately the victim behaved is, unfortunately, not an obsolete practice. See Skelton, Court of Appeal Weighing Student's Novel Tort Claim. The Recorder, Feb. 19, 1991, at 17, col. 1 (Umiversity of California at Berkeley student's claim that she was raped by four football players was not criminally prosecuted; Alameda County District Attorney said victim was not credible because she had been drinking; the D.A. said that group-rape cases are rarely prosecuted because victims frequently have been drinking).

25. "Nonconsent has traditionally becn a required element in the definition of a number of crimes, including theft, assault, and battery." Estrich, supra note 15, at 1121. 
extent possible. ${ }^{26}$ The rationale for the resistance requirement was that if the victim did not continuously resist, then she probably secretly enjoyed the encounter, or at least failed to give the inan notice that her "no" was not inere coy flirtation. ${ }^{27}$ Yet the resistance requirement has never been part of other crimes. ${ }^{28}$ If the general fear were of fabricated crimes, then all victims would be required to resist, not just victims of rape. ${ }^{29}$

Arguably, rape's uniqueness accounts for this discrepancy. Women often consent to sex, while nobody would consent to assault, nurder, or theft. Therefore, a strict requirement for nonconsent is necessary to protect defendants against false rape charges. This reasoning, however, merely echoes the pervasive distrust of rape victims within our justice system. The point is that while women inay consent to sex, they would never consent to rape. Should the law enshrine Matthew Hale's suggestion $^{30}$ that women are prone to report a rape and serve as witnesses against men with whom they have had consensual sex? Hale's approach to rape victims is inconsistent with the law's general approach to victims and defendants in all other crimes but rape.

Susan Estrich summarizes criminal law's umque treatment of rape:

That the law puts a special burden on the rape victim to prove through her actions her nonconsent (or at least to account for why her actions did not demonstrate "nonconsent"), while imposing no similar burden on the victim of trespass, battery, or robbery, cannot be explained by the oftobserved fact that consensual sex is part of everyday life. Visiting (trespass with consent) is equally common, as is philanthropy (robbery with consent) and surgery (battery with consent). Instinctively, we may think it is easier in those cases to tell the difference between consent and nonconsent. But if so, it is only because we are willing to presume that men are entitled to access to woinen's bodies (as opposed to their houses or their wallets) at least if they know them, and to accept male force in potentially "consensual" sexual relations. ${ }^{31}$

Another reason advanced in support of the resistance requirement was its supposed ability to prevent false clains of rape caused by cultural

26. Id. at 1122-23 ("Not only must there be entire absence of mental consent or assent, but there must be the most vehement exercise of every physical means or faculty within the woman's power to resist the penetration of her person, and this must be shown to persist until the offense is consummated." (quoting Brown v. State, 127 Wis. 193, 199, 106 N.W. 536, 538 (1906))).

27. Id. at 1127-30.

28. Id. at 1125 .

29. For an articnlate illustration of this double standard, see The Legal Bias Against Rape Victims, 61 A.B.A. J. 464, 464 (1975) (hypothetical cross-examination of a robbery victim, insinuating that his expensive suit and history of philanthropy was evidence that he was "asking" to be robbed).

30. 1 M. Hale, The History of the Pleas of The Crown 634 (1778) ("[R]ape is . . . an aceusation easily to be made and hard to be proved, and harder to bc defended by the party accused, tho never so innocent."), quoted in Estrich, supra note 15, at 1094-95.

31. Estrich, supra note 15, at 1126 (footnote omitted). 
taboos regarding female sexuality. At the time the doctrine developed, women were subjected to such severe sanctions for extramarital sex ${ }^{32}$ that they had a disincentive to admitting to engaging in it voluntarily. Thus, goes the reasoning, they might "cry rape" rather than admit to consensual sex.

When reformers succeeded in eradicating the resistance requirement, they opened the door to the mistake defense. ${ }^{33}$ Prior to the eradication of the resistance requirement, a case was not prosecuted if the victim's behavior was at all ambivalent. ${ }^{34}$ The mistake defense was not commonly used. Defense attorneys no doubt realized that claiming mistake would be implausible where the victim had attempted to fight off her attacker.

Now, with no resistance requirement, rape cases are prosecuted even where a woman lies still or feigns cooperation. In those situations, the defendant can more plausibly argue that he thought the victim consented. ${ }^{35}$ Thus, the increased use of the mistake defense may create an implicit resistance requirement. Rape jurisprudence could develop to the point where ouly plysical resistance is sufficient to overcoine the defendant's claim of mistake. ${ }^{36}$

While eradication of the resistance requirement freed rape law of

32. Such sanctions ranged from "stoning" in biblical times, see A. DWORKIN, INTERCOURSE 156 (1987) (quoting Deuteronomy 22:20-21), to economic punishment caused by the male breadwinner's rejection of a spouse or daughter who disregarded sexual taboos, cf. $\mathbf{S}$. BrowNMILlER, supra note 21, at 330 (women, "tainted" by rape, have been divorced by their husbands). The legal system's traditional approach to rape shows not only a male bias, see supra text accompanying note 23 , but, more specifically, a privileged white male bias. Consider, for example, the "Scottsboro trial," Patterson v. State, 224 Ala. 531, 141 So. 195, cert. granted sub nom. Powell v. Alabama, 286 U.S. 540, rev'd and remanded, 287 U.S. 45 (1932), in which mine young Southern black men were accused of raping two white women. One of the women recanted her accusations after several of her attackers had been sentenced to death. Angela Davis points out that "the rape charge has been indiscriminately aimed at Black men, the guilty and innocent alike." A. DAVIS, WOMEN, RACE \& CLASS 172 (1983). Between 1930 and 1967, 405 of the 455 men executed for rape were black. Id. If white men were threatened by black men's supposedly uncontrollable sexuality, these same white men offered the uncontrollable sexuality of black people as an excuse to rape black women. Id. at 182-83. Since slave days, the legal system has allowed white inen free access to black women's bodies. Sexual coercion was an important way for slaveowners to control slaves. Id. at 175-76. This idea has been extended from black women to women of color in general and working class women (for example, U.S. soldiers nsed rape to terrorize Vietnamese women during the Vietnam war). Id. at 177, 200. The cousequence of these stereotypes is that a woman of color or a working class woman may be less likely to be believed if she reports a rape. This would be especially true if the alleged rapist is white. Cf. id. at 200-01.

33. Dettmar, Culpable Mistakes in Rape: Eliminating the Defense of Unreasonable Mistake of Fact as to Victim Consent, 89 Dick. L. REv. 473, 481 (1984). Although the defense of mistake was always part of the cominon law, courts were more willing to permit jury instructions on mistake after resistance was no longer a requirement. Apparently, courts feared that, without the resistancc requireinent, rape defendants could be convicted too easily. Id.

34. Id. at 479-81.

35. See Coinment, supra note 16 , at $148-49$.

36. Given the terror and uncertainty of an attack situation, courts should not require 
one of its more obvious stereotypes, other stereotypes persist. According to Estrich, the stereotypical idea that women do not know what they want sexually explains the suspicion with which the modern judicial system regards rape victims. ${ }^{37} \mathrm{~A}$ wornan's incapacity clearly to decide whether she wants to have sex makes her "no" ineaningless. According to this stereotypical analysis, "the presence of force does not even prove rape, because many women enjoy and depend on force."38

According to the traditional analysis, whether "no" means "no" depends on what kind of woinan the victim is. A woman's sexual life'style has always been one of the prime criteria for deciding whether her "no" indeed means "yes." Thus, a "no" from a "good girl" unight be respected, while a "no" from a "bad girl" might not. This diclotoiny captures both the idea that sexually experienced woinen do not tell the truth and the idea that a wounan who consents to sex once has a propensity to consent again and again.

This Comment challenges the traditional view of women as incapable of articulating whether they want to have sex. Unfortunately, this view is perpetuated in male expectations of fernale sexual conduct and hence $m$ the legal system's treatment of the mistake of fact defense.

\section{B. The Mens Rea of Rape and the Mistake of Fact Defense}

The second element in the defimition of rape is mens rea or guilty mind. The mens rea required for rape is usually the intent to lave sex with a woman without her consent. ${ }^{39}$

As a general matter, mistake of fact is a valid defense to a crime if the mistake negates the mental state needed to establish an eleinent of that crime. ${ }^{40}$ As apphied to a rape prosecution, the defense of inistake of fact regarding the victim's consent asserts that even if the victim did not consent, the defendant thought she did and thus lacked the intent to have sexual intercourse with a nonconsenting woinan. ${ }^{41}$ A state's treatment of the mistake defense depends on whether the state explicitly or implicitly requires an intent for rape and on whetlier it requires mistakes to be reasonable.

The lack of a clear defimition of the mens rea requirement for rape is

resistance in all circumstances. A woman should be free to judge whether, in the particular situation, she risks injury if she resists.

37. Estrich, supra note 15 , at 1129 .

38. Id.

39. Katz, supra note 22 , at 48.

40. W. LAFAVE \& A. SCOTT, JR., supra note 20, at 405.

41. See, e.g., People v. Mayberry, 15 Cal. 3d 143, 542 P.2d 1337, 25 Cal. Rptr. 745 (1975) (trial court erred by not instructing jury to acquit if they had a reasonable doubt as to whether the defendant reasonably and genuinely beheved that the victim consented). For a discussion of this defense in the context of the Doe case, see infra text accompanying notes 98-105. 
demonstrated by the differing approaches to the issue of whether a mistake must be reasonable to exonerate the defendant. The majority of American jurisdictions require that a mistake be both honest and reasonable. ${ }^{42}$ This definition adopts a negligence standard for criminal hability. ${ }^{43}$ A defendant is negligent, and may be convicted of rape, if a reasonable person in his situation would have realized that the victim did not consent to sex. ${ }^{44}$

In a minority of American jurisdictions, as well as in Britain, an unreasonable but honest mistake as to consent is a defense to rape. ${ }^{45}$ Thus, the defendant may not be criminally punished for falling below the standard of care of a reasonable person. ${ }^{46}$

II

\section{Sexual History Evidence and the Purpose of Rape SHIELD STATUTES}

\section{A. Types of Sexual History Evidence}

Sexual history evidence is usually divided into three basic types: specific instances of the victim's conduct ( $V$ had sex with $X$ on Septeinber 20th); opinions of the victim's sexual practices ("It is iny opimion that V has had sex with inany people"); and evidence of the victim's reputation ("I have heard it said around the community that $\mathrm{V}$ is sexually experienced"). Pre-shield practices allowed hiberal use of all three forms of sexual history evidence in rape cases, subject only to general restrictions placed on the adinissibility of all evidence. ${ }^{47}$

42. See Berger, Man's Trial, Woman's Tribulation: Rape Cases in the Courtroom, 77 Colum. L. REv. 1, 61 n.360 (1977); Katz, supra note 22, at 53; see, e.g., Mayberry, 15 Cal. 3d at 157, 542 P.2d at 1346, 25 Cal. Rptr. at 754 (only reasonable mistake exonerates a rape defendant).

43. Katz, supra note 22, at 53 (Mayberry, a leading American case, "firmly establish[ed] a negligence mens rea with regard to consent.").

44. See Dettmar, supra note 33 , at 488 . Courts sometimes characterize negligence in a criminal context as criminal negligence or gross negligence. See generally $\mathrm{W}$. LAFAVE \& A. ScoTT, $\mathrm{J}_{\mathrm{R} .,}$ supra note $20, \S 3.7(\mathrm{~b})$, at 235-37 (discussion of criminal negligence). However, these additional labels generally are not defined, and in any event seem to contemplate a similar standard. Id. "[A] few cases have quite clearly spelled out that while no greater risk of harm is required for criminal than for tort hability, ... there is a difference between the two: the defendant must realize the risk for criminal law though he need not for tort law." Id. at 236. The opposing view is that the defendant need not subjectively realize the risk but that the risk must be greater for criminal than for tort liability. Id. at 235 .

45. See Katz, supra note 22, at 48-51, 53-54 (analyzing Director of Public Prosecutions v. Morgan, 2 All E.R. 347 (1975), and Reynolds v. State, 644 P.2d 621 (Alaska Ct. App. 1983), both holding that an unreasonable but honest mistake as to consent was defense to rape).

46. See Katz, supra note 22 , at $48-49$ (The debate between reasonable and unreasonable mistake translates into "a debate about which mens rea going to the attendant circumstance of the victim's consent is necessary for liability: recklessness or negligence. . . The Morgan rule [exonerating the defendant based on unreasonable mistake] holds that [no] kind of neghigent mistake as to consent is consistent with criminal liability for rape.").

47. See infra notes $68-73$ and accompanying text. 


\section{B. The Traditional Use of Sexual History Evidence}

Before the enactment of rape shield laws, rape victims were considered fair game for so-called character assassimation based on their sexual histories. ${ }^{48}$ This practice was rooted in the original treatment of rape as a crime agamst a man's property (that is, his wife or daughter), the value of which was diminished by sexual intercourse out of wedlock. "Chastity" was the sime qua non of rape. If a woman was not chaste, her value had already been diminished and the defendant could not be guilty of rape.

Traditionally, sexual history evidence had two mam uses. First, it could show consent: a sexually experienced woman supposedly casually selects sexual partners and was thus more likely to have consented to the act in question. ${ }^{49}$ A famous opinion stated the legal systein's view of sexually experienced women as follows:

[W]ill you not more readily infer assent in the practiced Messalina, in loose attire, than in the reserved and virtuous Lucretia? ${ }^{50}$

Presumably the answer to this hypothetical question was a resounding "yes" from all-male juries and the legal system. The assumption that a sexually experienced woman is more likely to consent remains in our legal system today. Only recently, a former Ohio judge, John Angelotta, boldly asserted on national television that:

A rice girl who gets raped is different than a bad girl who gets raped, a bad girl being one who carries on this course of conduct with men. To me, she's a lot different than a good girl when you coine to the question of rape-while agreeing that you may not rape either kind of girl. ${ }^{51}$

The assumption that a consenting woman, the so-called bad girl, would take the time and trouble to report a rape, bearing the humiliating ordeal that traditionally followed, went unquestioned.

Sexual history evidence was also used to show a propensity for dishonesty. ${ }^{52}$ A woman with sexual experience outside of marriage was

48. See generally Katz, supra note 22, at 34-37 (discussing the use of sexual history evidence to show "character").

49. Kneedler, Sexual Assault Law Reform in Virginia-A Legislative History, 68 VA. L. REV. 459, 486-87 (1982).

50. People v. Abbot, 19 Wend. 192, 195 (N.Y. 1838).

51. Angelotta v. American Broadcasting Corp., 820 F.2d 806, 806-07 (6th Cir. 1987) (suit by judge alleging that television program falsely portrayed him as biased against rape victins); see also Simonson v. United Press Int'l, 654 F.2d 478, 479-80 (7th Cir. 1981) (statement of judge at sentencing hearing for juvenile convicted of rape, which led to the judge being recalled: "Even in open court we have people appearing-women appearing without bras and with the nipples fully exposed ... and we have this type of thing in the schools. ... [A]re we supposed to take an impressionable person 15 or 16 years of age who can respond to something like that and punish that person severely because they react to it normally?').

52. Berger, supra note 42 , at $16,65-68$. 
assumed to be untruthful. ${ }^{53}$ This was consistent with the equation of female chastity with self-worth and honesty. Sexual experience, however, was behieved to have no effect on men's veracity. ${ }^{54}$ Special requirements for rape cases, such as evidence corroborating the victim's assertions, confirmed the suspicion with which the male legal system viewed a woman who pointed the finger at their brethren. ${ }^{55}$

\section{The Purpose of Rape Shield Statutes}

As attitudes about women's role in society changed, and women emerged from centuries of male domination im the legal and im other professions, assumptions about female sexuality reflected in the cominon law of rape came under fire. Although it is premature to assert that gender role stereotyping no longer exists, progress in the area of male/female relations has prompted basic changes im the legal system. Among these changes was the enactment of rape shield statutes.

Rape shield statutes ${ }^{56}$ were enacted to serve five basic purposes. The first was to protect the privacy of rape victims. ${ }^{57}$ Before rape shield statutes were enacted, minute details of the victim's private life could be discussed in the courtroom.

A second, and related, purpose, of rape shield statutes was to encourage rape victims to come forward. ${ }^{58}$ The statutes attempt to achieve this end by banning humiliating and intrusive questions about rape victims' sexuality. ${ }^{59}$ Representative Elizabeth Holtzman of New York, drafter of the federal rape shield statute, phrased the problem as follows:

Nonchalance about rape is aggravated by the fact that, in the Federal systein and in inany States, our laws may add to the shock and horror of rape by allowing a viction to be treated in the courts in a fashion that inplies that rape was somehow her own fault. The consequence has been the enormous reluctance of women to report the crime and subject themselves to a second ordeal. ${ }^{60}$

53. Id. at 16 .

54. Id.

55. Id. at 19-22.

56. For a discussion of some of these statutes, see infra notes 74-91 and accompanying text.

57. See President's Statement on Signing H.R. 4727 into Law, 14 WeEkLY CoMP. PrES. Doc. 1902 (Nov. 6, 1978) [heremafter President's Statement] (bill designed to prevent defendants from making victims' private lives an issue at rape trials).

58. Privacy of Rape Victims: Hearings on H.R. 14666 Before the Subcomm. on Criminal Justice of the House Comm. on the Judiciary, 94th Cong., 2d Sess. 23 (1976) [hereinafter Privacy of Rape Victims] (estimating the number of reported rapes as one in five).

59. These types of questions could include, for example, inquiries regarding whether the victim was sexually experienced and whether she enjoyed the encounter in question. See Katz, supra note 22 , at 34.

60. Privacy of Rape Victims, supra note 58, at 2 (statement of Rep. Elizabeth Holtzman). 
A third purpose of rape shield statutes was to enhance the accuracy of the outcomes in rape trials by excluding irrelevant or prejudicial evidence. $^{61}$ Rape shield statutes reflect a new consensus that a woman's sexual past has a low probative value, if any value at all, in a rape trial. ${ }^{62}$ Holtzinan summarized this purpose:

[M]y bill takes the position that whether or not a woman has ever said yes im the past is absolutely irrelevant to whether she would have said yes at the present time-to the present defendant. Whether a woman says yes or no to a particular man depends on the circumstances of that relationship. ${ }^{63}$

These statutes also enhance accuracy by inaking it clear that the defendant, not the victim, is on trial. ${ }^{64}$

The fourth and fifth purposes of rape shield statutes are related. The fourth purpose is deterrence. Rape shield statutes send a clear message to attackers that "bad girls" are not fair game. Would-be rapists are deterred by the knowledge that they will be punished for rape regardless of whether their victim is sexually experienced. Rape shield statutes also further the deterrence goal by encouraging victims to report rapes. A greater percentage of reported rapes leads to more prosecutions and more rape convictions. A would-be rapist whose friend was prosecuted and jailed for the same behavior inight be less likely to act on his desire to rape.

Rape shield statutes also serve a fifth purpose: protecting the autonoiny of woinen. The message that bad girls are not fair game makes it clear that a wornan's choice of sexual lifestyle will not affect the extent of rape law protection she receives. Thus a woman's freedom to choose her sexual partners is not thwarted by the assumption that if she consents to sex once, she loses her legal right to say no.

\section{The Federal Rape Shield Statute}

The Federal Rules of Evidence govern proceedings in the courts of

61. A recent New Jersey study illustrates the prejudicial effect of evidence regarding past sexual history. In the study, $66 \%$ of those surveyed felt that women provoke rape by their appearance or behavior. H. FElLD \& L. BlENEN, supra note 4, at 50-51.

62. Sexual history evidence is, however, considered probative if it concerns sexual acts with the defendant. Most rape shield statutes allow evidence of the victim's sexual acts with the defendant to be introduced on the issue of consent. See, e.g., FED. R. Ev1D. 412(b)(2)(B).

63. Privacy of Rape Victims, supra note 58, at 45 (emphasis added).

64. See id. at 36,57 (witnesses explaining how a pre-shield rape trial was like a second rape because of the humiliation the victim underwent). The prospect of this humiliation deters some women from going to the police. The race and social class of the victim and her attacker further influence whether or not the rape will be reported and how it will be treated by the judicial system. See supra note 32 . 
the United States. ${ }^{65}$ Federal Rule of Evidence 401 defines relevant evidence $^{66}$ and Federal Rule of Evidence 402 states the general rule that "[e]vidence which is not relevant is not admissible."

Prior to the enactnient of the federal rape shield statute, sexual history evidence was admissible, subject to three main exceptions. First, the evidence could be excluded under Federal Rule of Evidence 403 if it was more prejudicial than probative. ${ }^{68}$ Second, it could be excluded under Rule 404 as character evidence, which was inadmissible to show that the victim acted "im conformity therewith on a particular occasion."69 Third, sexual history evidence could be excluded under Rule 608, when the victim took the stand, if it was not considered probative of the victim/witness' veracity. ${ }^{70}$

Unfortunately, these exceptions were not usually used to exclude sexual history evidence in rape cases. First, sexual history was considered more probative than prejudicial on the issue of consent and was therefore admissible. ${ }^{71}$ Second, there was an exception to the character evidence exclusion for a pertinent "character trait" of a crimie victim offered by a criminal defendant. ${ }^{72}$ A rape victim's frequent consent to sex was considered a character trait. Third, sexual history evidence was traditionally considered probative of the victim/witness' veracity and therefore admissible. ${ }^{73}$ The end result was that sexual history evidence was almost always admitted.

On October 30, 1978, President Jimmy Carter signed into law H.R. 4727, which created Federal Rule of Evidence 412, the rape shield statute. ${ }^{74}$ The rule was the result of a long, bitter struggle by groups and

65. FED. R. Ev1D. 101. Of course, state courts are governed by the states' own rules of evidence.

66. Id. Rule 401 .

67. Id. Rule 402 .

68. Id. Rule 403. The text of the rule is reproduced at infra note 113 . There was also a relevance limitation, but prior to the enactment of rape shield statutes sexual history evidence was considered relevant.

69. Id. Rule 404 . Thus, the law has rejected the maxim "once a thief, always a thief."

70. Id. Rule 608.

71. See supra notes $49-51$ and accompanying text.

72. FED. R. EvID. 404(a)(2).

73. For a discussion of the common law equation of sexual experience with dishonesty, sec supra notes 52-55 and accompanying text.

74. President's Statement, supra note 57, at 1902. The President issued the following statement:

This bill provides a model for state and local revision of criminal and case law. It is designed to end the public degradation of rape victims and, by protecting victims from humiliation, to encourage the reporting of rape. ... Too often rape trials have becn as humiliating as the sexual assault itself. By restricting testimony on the victim's prior sexual behavior to that genuinely relevant to the defense, the rape victims act will prevent a defendant from making the victim's private life an issue in the trial.

Id. Rule 412 reads in relevant part:

Sex Offense Cases; Relevance of Victim's Past Behavior 
individuals concerned with effective law enforcernent and equal treatinent for woinen. ${ }^{75}$ Rule 412 prohibits the introduction at trial of reputation or opinion evidence of a rape victim's sexual history. ${ }^{76}$ The premise for this ban, as' stated by Representative Holtzinan, was that evidence of a victim's prior consensual sexual encounters was irrelevant to the issue of whether the victim consented at a particular tine with a particular person. ${ }^{77}$

Rule 412 also prohibits introduction of sexual history evidence not in reputation or opinion form, ${ }^{78}$ subject to three exceptions. The first exception concerns evidence which a rape defendant has a constitutional right to introduce. ${ }^{79}$ The second exception is for evidence of the victim's sexual behavior with persons other than the defendant, which the defendant offers to show that he was not the source of seinen or injury. ${ }^{80}$ The final exception is for past sexual behavior of the victim with the defendant himself, which the defendant offers to show consent. ${ }^{81}$ Even if the

(a) Notwithstanding any other provision of law, in a criminal case in which a person is accused of an offense under chapter 109A of title 18, United States Code, reputation or opinion evidence of the past sexual behavior of an alleged victim of such offense is not admissible.

(b) Notwithstanding any other provision of law, in a criminal case in which a person is accused of an offense under chapter 109A of title 18, United States Code, evidence of a victim's past sexual behavior other than reputation or opinion evidence is also not admissible unless such evidence other than reputation or opinion evidence is-

(1) admitted in accordance with subdivisions (c)(1) and (c)(2) [concerning procedural requirements] and is constitutionally required to be admitted; or

(2) admitted in accordance with subdivision (c) and is evidence of-

(A) past sexual behavior with persons other than the accused, offered by the accused upon the issue of whether the accnsed was or was not, with respect to the alleged victim, the source of semen or injury; or

(B) past sexual behavior with the accused and is offered by the accused upon the issue of whether the alleged victim consented to the sexual behavior with respect to which such offense is alleged.

FED. R. EVID. 412 (procedural sections omitted).

75. The Subcommittee on Criminal Justice of the House Conumittee on the Judiciary held hearings on the proposed bill. Groups represented in the hearings included: the Department of Justice, the American Bar Association, the National Organization of Women, the Rape Victim Companion Program, the Tidewater Rape Inforniation Servicc, and the American Civil Liberties Umion, as well as distinguished individuals such as Professor Laurence Tribe, and Judge Patricia Boyle, Detroit Recorder's Court. Privacy of Rape Victims, supra note 58, at III. The coalition supporting Rule 412 consisted of traditionally conservative law-and-order types and traditionally hberal femmists. This unlikely combination may have accounted for sone of Rule 412's less progressive aspects. See infra notes 157-58 and accompanying text (discussing the Rule 412(b)(2)(B) exception for evidence of the victim's past sexual conduct with the defendant).

76. FED. R. EvID. 412(a).

77. See supra text accompanying notes 62-63.

78. FED. R. EVID. 412(b). Sexual history evidence in fornis other than reputation or opinion evidence usually involves specific instances of conduct such as the victim's sexual encounter with a specific person on a specific day.

79. Id. Rule 412(b)(1). For a discussion of when the Constitution might conupel the admission of sexual history evidence to show mistake, sec infra notes 161-67 and accompanying text.

80. Id. Rule 412(b)(2)(A).

81. Id. Rule 412(b)(2)(B). 
evidence fits into one of the latter two categories, it is admissible only if the trial judge finds, after an in camera hearing, that it is both relevant and more probative than prejudicial. $^{82}$ No provision in Rule 412 addresses the issue of sexual history evidence offered to support a mistake defense. ${ }^{83}$

The testimony and ensuing debates during the struggle to enact Rule 412 failed to discuss how the new rule would treat sexual history evidence offered to support a mistake defense. Indeed, Representative Holtzman reiterated in one exchange that she was "just talking about the issue of consent."84 Thus, when federal courts confront the issue of sexual history evidence offered to support a mistake defense, they may look for guidance neither to the text of Rule 412 nor to the legislative history surrounding its enactinent.

\section{E. State Rape Shield Statutes}

Most state statutes follow the basic contours of Federal Rnle of Evidence 412. Many states, however, do not expressly provide an exception for evidence constitutionally required. ${ }^{85}$ Other states ban sexual history evidence subject to an exception only for specific instances of conduct with the defendant. ${ }^{86}$

82. Id. Rule 412(c).

83. Nonetheless, the Fourth Circuit held that Rule 412's broad exclusion does not apply to sexual history evidence offered to support a mistake defense. Doe v. United States, 666 F.2d 43, 48 (4th Cir. 1981).

84. Privacy of Rape Victims, supra note 58, at 74.

85. See, e.g., Ala. CODE § 12-21-203 (1986); FlA. Stat. ANN. $\S 794.022(2)$-(3) (West Supp. 1991); GA. CoDe ANN. § 24-2-3 (1990); Ill. ANN. Stat. ch. 38, 7f 115-117 (Smith-Hurd Supp. 1990); IND. CODE ANN. § 35-37-4-4 (West 1986); KY. REv. STAT. ANN. § 510.145 (Michie/BobbsMerrill 1985); ME. R. CT. art. IV, Rule 412 (West 1990); MD. CoDE ANN. art. 27, \$ 461A (1987); MASS. GeN. LAws ANN. ch. 233, § 21B (West 1986); Mich. CoMP. LAws ANN. $\$ 750.520$ j (West Supp. 1990); MiNN. STAT. ANN. art. 4, Rule 404(c) (West 1980); Mo. ANN. STAT. $\$ 491.015$ (Vernon Supp. 1991); MONT. CODE. ANN. § 45-5-511(4) (1989); NEB. REV. STAT. § 28-321 (1989); N.H. REv. StaT. ANN. § 632-A:6 (1986); N.C. GEN. STAT. ch. 8C, Rule 412 (1990); OHIo Rev. Code ANN. § 2907.02(D) (Anderson 1987); 18 PA. Cons. STAT. ANN. § 3104 (Purdon 1983); S.C. CODE ANN. § 16-3-659.1 (Law. Co-op. 1985); TENN. CODE ANN. \$ 40-17-119 (1990); VT. STAT. ANN. tit. 13, § 3255 (Supp. 1990); VA. CODE ANN. $\S 18.2-67.7$ (1988); W. VA. CODE $\S 61-8 B-11$ (Supp. 1989); WIS. STAT. ANN. §§ 971.31(11), 972.11(2) (West 1985 \& Supp. 1990).

86. See, e.g., CAL. EvID. CoDE $\S 1103(b)$ (West Supp. 1991). California's rape shield statute actually consists of two statutes. The first, section 782 of the Evidence Code, is merely a procedural statute. Id. $\$ 782$. The second statute, section $1103(\mathrm{~b})$ of the Evidence Code, contains the substantive provisions, and provides in relevant part:

(1) [O]pinion evidence, reputation evidence, and evidence of specific instances of the complaining witness' sexual conduct, or any of such evidence, is not admissible by the defendant in order to prove consent by the complaining witness.

(2) Paragraph (1) shall not be applicable to evidence of the complaining witness' sexual conduct with the defendant.

(3) If the prosecutor introduces evidence, ... or the complaining witness as a witness gives testimony, and such evidence or testimony relates to the complaining witness' sexual conduct, the defendant may cross-examine the witness who gives such testimony and offer 
Both the latter type of statute and the federal rule would ban evidence showing, for exainple, that the victim had sexual relations with the majority of inen in a fraternity, if the trial concerned the victim's claim that one of the fraternity inembers had raped her. In some situations, the outcomes under the two types of statutes would differ. Rule 412 would not bar evidence of an injury (such as a venereal disease) which the victim's sexual history would allegedly explain, ${ }^{87}$ while states with only a "conduct with the defendant" exception would ban such evidence.

The state of Georgia has a unique rape shield statute, revised in $1989,{ }^{88}$ with one of the most thorough bans on sexual history evidence. In passing this statute, the Georgia Legislature has solved the problem of sexual history evidence offered to support a mistake defense. The statute bans any evidence of the victim's sexual history in a rape prosecution unless the evidence both directly involves the participation of the defendant and supports an inference that the defendant could reasonably have believed that the victim consented to the encounter. ${ }^{89}$ Unlike the federal statute which does not bar evidence of prior sexual conduct with the defendant, Georgia's statute would bar such evidence uuless the conduct could have led a reasonable person to mistakeuly believe in consent. Therefore, past sexual history that does not involve the defendant cannot be used to support a mistake defense. Applying this statute to the above hypothetical, the defendant could only introduce evidence of the victim's activities with the fraternity members if lie directly participated and if his

relevant evidence limited specifically to the rebuttal of such evidence introduced by the prosecutor or given by the complaining witness.

(4) Nothing in this subdivision shall be construed to make inadmissible any evidence offered to attack the credibility of the complaining witness . . . .

Id. § 1103(b); see also DEL. CODE ANN. tit. 11, §§ 3508, 3509 (1985); MISs. CoDE ANN. §§ 97-3-68, -70 (Supp. 1990); Nev. Rev. STAT. ANN. $\S 50.090$ (Michie 1989); N.D. CeNT. Code $§ \S 12.1-20-14$ to -15 (1985); OKLA. STAT. ANN. tit. 22, § 750 (West Supp. 1991); WASH. REV. CODE § 9A.44.020 (1988).

87. FED. R. EvID. 412(b)(2)(A).

88. GA. CODE ANN. $\S 24-2-3$ (1990). The statute provides in relevant part:

(a) In any prosecution for rape, evidence relating to the past sexual behavior of the conplaining witness shall not be admissible, either as direct evidence or on crossexamination of the complaining witness or other witnesses, except as provided in this Code section. For the purposes of this Code section, evidence of past sexual behavior includes, but is not linited to, evidence of the complaining witness's narital history, mode of dress, general reputation for promiscuity, nonchastity, or sexual mores contrary to the community standards. (b) In any prosecution for rape, evidence relating to the past sexual behavior of the complaining witness may be introduced if the court ... finds that the past sexual behavior directly involved the participation of the accused and finds that the evidence expected to be introduced supports an inference that the accused could have reasonably believed that the complaining witness consented to the conduct complained of in the prosecution.

89. Id. $\S 24-2-3(\mathrm{~b})$. The necessary procedures for offering sexual history evidence include an in camera hearing. Id. $\S 24-2-3(c)$. 
mistaken belief in consent based on the prior activity could be termed reasonable. $^{90}$

At the opposite extreme from Georgia's restrictive statute, a minority of states leave the decision of whether to admit sexual history evidence completely within the trial judge's discretion. ${ }^{91}$ The judge must simply determine whether the evidence is relevant. Presumably, the judge's finding would be reviewable on an abuse of discretion standard, as would any determination of relevance. This approacl, however, fails to address the prejudices and stereotypes that characterized the traditional use of sexual history evidence.

In suin, altliougli there are several deviations from the federal statute, the majority of states follow the basics of Rule 412. Georgia's is the only statute which resolves the question of whetler to admit sexual history evidence to support a mistake defense. Ouly Georgia has taken steps to solve the problem presented here. Other states, like the federal courts, still lack legislative guidance in this area.

\section{III \\ The Treatment of Sexual History Evidence IN Mistake Cases UNDER THE RAPE Shield STATUTES}

Evidence of a rape victim's sexual history could be offered to support a mistake of fact defense, using the following chain of inferences: The victim was reputed to be sexually experienced; the defendant knew of this reputation; sexually experienced wornen are widely seen as being more likely to consent in a given situation; ${ }^{92}$ thus, the defendant thought the victim was sexually available although she did not explicitly indicate consent.

As previously noted, inost rape shield statutes do not explicitly treat the mistake defense. ${ }^{93}$ Most statutes make evidence of the victim's sexual past inadmissible on the issue of consent. ${ }^{94}$ The critical question is whetlier the word "consent" is intended to include the defendant's mis-

90. The 1989 revision substantially changed the Georgia statute. Prior to that revision, there were two exceptions: one for sexual history evidence directly involving the defendant and another for any type of sexual history evidence supporting a reasonable behef in consent. The revision probably resulted from a particularly harsh Georgia case in which the victim of a gang rape was cross-examined on every detail of her sexual history because the defendants offered mistaken belief in consent as a defense. See Hardy v. State, 159 Ga. App. 854, 285 S.E.2d 547 (1981). For a discussion of Hardy, see infra notes 120-23 and accompanying text.

91. See, e.g., AlASKa STAT. \$ 12.45.045(a) (1990).

92. See, e.g., supra text accompanying note 51 .

93. See, e.g., FED. R. Evid. 412. But see GA. CODE ANN. $\$ 24-2-3$ (1990). For a discussion of the Georgia rape slield law, see supra notes 88-90 and accompanying text.

94. See, e.g., CAL. Evid. CoDE $\S 1103(b)(1)$ (West Supp. 1991). Generally, this ban allows an exception for tlie victim's prior sexual activity witlı tlte defendant. See, e.g., id. $\S 1103(\mathrm{~b})(2)$. 
taken belief in consent. An analytically justifiable answer to this question must comport with the five purposes behind the rape shield statutes, ${ }^{95}$ steering clear of the stereotypes about women's sexuality that characterized traditional rape law. With this standard in mind, we move on to the present case law on sexual history evidence offered to support a mistake defense. Unfortunately, a uniform theoretical understanding of the application of rape shield statutes in the mistake context is notably absent from the opinions that follow. As a result, some courts risk reverting to discredited perceptions of rape.

\section{A. The Doe Approach}

Although federal law directly affects only a small percentage of rape cases, ${ }^{96}$ the federal courts' treatment of rape is iniportant because many states pattern both their rape shield laws and their substantive rape laws on federal law. ${ }^{97}$ The major federal case dealing with the interplay of the inistake of fact defense with Federal Rule of Evidence 412 is Doe v. United States. ${ }^{98}$ In Doe, the defendant offered evidence that the victim was sexually experienced to show that she had consented to intercourse or, alternatively, that he reasonably believed she liad. ${ }^{99}$ The trial court held that evidence of the victim's past sexual history, although inadmissible to show consent, could be admitted to show the defendant's state of mind. The Fourth Circuit affirmed. ${ }^{100}$ In a sweeping statement, the Fourth Circuit found that:

The legislative history [of Rule 412] discloses that reputation and opinion evidence of the past sexual behavior of an alleged victim was excluded because Congress considered that this evidence was not relevant to the issues of the victim's consent or her veracity. There is no indication, however, that this evidence was intended to be excluded when offered solely to show the accused's state of mind. Therefore its adımission is governed by the rules of evidence dealing with relevancy in general. ${ }^{101}$

According to the Doe court, evidence that the victim is sexually experienced (even in reputation or opinion form) is admissible if the defendant offers his mistaken behief in consent as a defense and shows that his knowledge of the victini's sexual history led to this belief. The court found that the defendant's knowledge of the victim's sexual history

95. See supra notes 56-64 and accompanying text.

96. For a rape case to come to trial in federal court, the alleged attack must occur either within the areas of special maritime and territorial jurisdiction of the United States, see 18 U.S.C. $\$ \S 2241$ 2242 (1988), or on an Indian reservation, see id. $\$ 1153$.

97. See, e.g., HAw. REV. STAT. $\S 626-1$, Rule 412 (1988) (adopting the provisions of the federal rape shield statute).

98. 666 F.2d 43 (4th Cir. 1981). The United States Supreme Court has yet to address the issue.

99. Id. at 47.

100. Id. at 48 .

101. Id. (emphasis added) (citation omitted). 
was relevant on the issue of his intent. ${ }^{102}$

The defendant in Doe acknowledged that his behef in consent had to be reasonable to exonerate him. ${ }^{103}$ In admitting this evidence, the court endorsed the defendant's theory that the victim's reputation for having sexual relations with inany Army men could lead a reasonable person to beheve mistakenly in consent. ${ }^{104}$ The court noted that this evidence was ouly admissible on the issue of the defendant's state of mind, not on the issue of whether the victim consented. 105

Solne commentators have criticized Doe for ignoring the plain language of Rule 412. ${ }^{106}$ Rule 412(a) states that reputation and opimion evidence are never adimissible. ${ }^{107}$ The rule's langnage is not limited to evidence offered to prove consent or to show lack of veracity. ${ }^{108}$ Doe's narrow reading of the language of Rule 412 ignores the underlying pohcies of the rule. Indeed, the Doe court's critical error was to leave untouched the important issue of whether its holding served the policies behind Rule 412.

The finding in Doe, that a woman's sexual experience could lead a reasonable person to believe in consent, undermines the purposes behind Rule 412. Doe's holding tliwarts the goal of protecting the privacy of rape victims. A rape victim's privacy should not be invaded in the name of the mistake defense any inore tlian in the name of the consent defense. Admitting evidence of a woman's sexual history under the guise of the mistake defense would vindicate those lolding stereotypical views of sexuality, as exeinplified by foriner Ohio judge John Angelotta. ${ }^{109}$ The fear of "having their personal lives and tlieir reputation questioned" would in turn thwart the second purpose behind Rule 412 by discouraging women froin reporting and prosecuting rapes. ${ }^{110}$

102. Id.

103. Id. at 47.

104. Id.

105. Id. at 47-48. Presumably, the prosecution could request a limiting instruction to this effect. In addition, the sexual history evidence could have been excluded under Federal Rule of Evidence 403 if the risk of unfair prejudice to the prosecution outweighed its probative value. For an example of a case so holding, see United States v. Saunders, 736 F. Supp. 698 (E.D. Va. 1990), discussed at infra notes 113-15 and accompanying text.

106. See, e.g., Spector \& Foster, Rule 412 and the Doe Case: The Fourth Circuit Turns Back the Clock, 35 OKLA. L. REV. 87, 96-97 (1982) (Rule 412 clearly excludes all character proof offered in the form of reputation or opinion testimony).

107. FED. R. EvID. 412(a).

108. Id.

109. See supra text accompanying note 51 .

110. See Privacy of Rape Victims, supra note 58, at 42 (testimony of Mary Ann Largen, National Organization for Women, about how women are deterred from reporting rapes based on the fear of courtroom humihation); see also id. at 50 (testimony of Cheryl Robinson, Volunteer Supervisor, Rape Victim Companion Program: "One woman felt that she would not be able to emotionally withstand a comparison of her past relationships with the violent sexual assault that had taken place. Another woman feared the destructive impact that answers to her questions about her 
The holding in Doe is also detrimental to the third purpose behind Rule 412, accuracy of outcome in rape trials. Jurors are often prejudiced by evidence showing a rape victim is sexually experienced. ${ }^{111} \mathrm{~A}$ limitimg instruction may prove meffective as long as attitudes such as "bad girls deserve it" continue to be widespread in our society: ${ }^{112}$

Finally, Doe's holding undermines the fourth and fifth purposes behind Rule 412, deterrence and sexual autonomy. Deterrence is illserved by exonerating rape defendants based on either so-called reasonable mistakes as to consent caused by knowledge that the victim consented to sex in the past, or, even worse, based on juror prejudice against the victim because of her sexual lifestyle. Rapists are not deterred from committing future rapes if their behavior goes unpumished due to their victims' sexual lifestyle. As for sexual autonoiny, a woman is hardly free to choose a sexual lifestyle when her choice may haunt her in court simply because defense counsel utters those magic words, "My chent thought the woman consented."

A recent decision from the Eastern District of Virginia provides an interesting application of Doe's holding. The court barred sexual history evidence offered to support a mistake defense because it found that the particular evidence offered, the victim's prior sexual encounter with an acquaintance of the defendant, was more prejudicial than probative under Federal Rule of Evidence 403. ${ }^{113}$ Since the Eastern District of Virginia is in the Fourtl Circuit, the court was bound by Doe's holding. The district court found it unnecessary to address the government's contention that Doe was wrongly decided. ${ }^{114}$ Rather, the court stated:

[T] he knowledge of his friend's alleged recent consensual sex with the alleged victim illuminates nothing relevant about the defendant's state of mind on the might of the alleged rape. Significantly, however, such evidence is fraught with the danger of unfair prejudice because it suggests to the jury that the alleged victim is "promiscuous" and therefore not worthy of either belief or protection from rape. ${ }^{115}$

past sexual history would have on her family. A third victim repeatedly considered dropping charges out of fear that her lifestyle would liave a negative impact on the case.").

111. See id. at 21 (testimony of Roger Pauley, Department of Justice: "American juries operate on sort of rudimentary principles of morality as they perceive it to such a degree that ... they were hikely to acquit a defendant, even though the Government had proved its case under the terms of the statute, and the elements of the offense, if they regarded the woman as a 'loose woman' who was fair game and who had someliow by her attitude, taken a libertine attitude toward sex-and perhaps in their eyes she contributed to the assault.").

112. See infra Section IV(A)(1) (discussing these attitudes).

113. United States v. Saunders, 736 F. Supp. 698, 704-05 (E.D. Va. 1990). Rule 403 reads: "Although relevant, evidence may be excluded if its probative value is substantially outweighed by the danger of unfair prejudice, confusion of the issues, or misleading the jury, or by considerations of undue delay, waste of time, or needless presentation of cumulative evidence." FED. R. Evid. 403.

114. Saunders, 736 F. Supp. at 704.

115. Id. It is interesting to note that, although well-meaning, the court's language reflects some 
Thus, the district court avoided the trap laid by the Doe decision. It implicitly recognized that the pohicies behind rape shield statutes would be compromised if evidence of the victim's prior consensual sexual experiences were admitted to show mistake. However, because the district court refused to criticize the Doe decision directly, tlie government's contention that Doe was wrongly decided was and still remains judicially unaddressed.

\section{B. Other Judicial Approaches to the Problem}

Other jurisdictions have adopted different approaches to the introduction of sexual history evidence to show mistake. In California, a reasonable good faith behef in consent is a defense to rape. ${ }^{116}$ A 1980 California appellate case found evidence of the victim's past sexual conduct with persons other than the defendant inadmissible to prove the defendant liad such a belief. ${ }^{117}$ The court's treatment of the issue was perfunctory. It cited as authority California Evidence Code section 1103, which bans sexual history evidence offered " in order to prove consent by the complaining witness.' "118 Thus, by implication, the court's argument was that the words "in order to prove consent" were intended by the legislature to encompass situations where the evidence was offered to prove a mistaken behef in consent. ${ }^{119}$ The court did not elaborate on this

of the same hurtful stereotypes discussed at infra Section IV(A)(1). For example, the court characterizes sexually experienced women as women of "easy virtue." Saunders, 736 F. Supp. at 704.

116. See People v. Mayberry, 15 Cal. 3d 143, 155, 542 P.2d 1337, 1345, 125 Cal. Rptr. 745, 753 (1975) (citimg CAL. Penal CoDE $\S 261(2)$-(3) (West 1988)) ("If a defendant entertains a reasonable and bona fide belief that a prosecutrix voluntarily consented to accompany him and to engage in sexual intercourse, it is apparent that he does not possess the wrongful intent that is a prerequisite ... to a conviction of . . . rape ...."). One coinmentator criticized Mayberry for circumventing "both the letter and the intent of the new rape evidence laws." O'Neale, Court Ordered Psychiatric Examinations of a Rape Victim in a Criminal Rape Prosecution-Or How Many Times Must a Woman Be Raped?, 18 Santa Clara L. Rev. 119, 132 (1978).

117. People v. Guthreau, 102 Cal. App. 3d 436, 444, 162 Cal. Rptr. 376, 380 (1980) (citing CaL. Evid. CoDE $\S 1103$ (West Supp. 1991)).

118. Id. (quoting CaL. Evid. Code $\S 1103(2)(b)$ (West Supp. 1991)).

119. Although the court's treatment of the issue was conclusory, its apparent understanding of the relationship between the consent defense and the reasonable mistake defense finds support in California law. See, e.g., People v. Hampton, 118 Cal. App. 3d 324, 329-30, 173 Cal. Rptr. 268, 27172 (1981) (holding that a defendant who relies on the consent defense "necessarily also relies" on the mistake defense, thus recognizing the close factual relationship of the two defenses). Another California appellate court reached the same conclusion in a much clearer manner, though the opinion was ordered depublished by the California Supreme Court on June 9, 1988. Discussing sexual history evidence offered to support a mistake defense, the court stated:

[T] he policy reasons that support exclusion of this evidence when offered to prove consent apply with equal force when the evidence is offered to prove a reasonable belief in the victim's consent. In addition, if the statute did not extend to ban admission of evidence when offered to prove a Mayberry [reasonable behef in consent] defense, its impact in consent cases would soon be circumvented by defendants alleging both defenses as a matter of routine. 
issue, nor did it offer a policy discussion to support its reading of the code.

An appellate court in Georgia reached the opposite result. In a case of an alleged gang rape by members of a college fraternity, the court found sexual history evidence admissible to support a mistake defense. ${ }^{120}$ The court stated:

[P]roof of prior consent without regard to identity of persons or similarity of circumstances may be admitted to allow the jury to weigh, or calculate as it were, the probability of consent with respect to an entire class of 'unchaste' women when the court finds that the evidence 'supports an inference that the accused could have reasonably believed that the complaining witness consented to the conduct complained of. ${ }^{121}$

At the timie this case was decided, the Georgia rape shield statute was less progressive than it is currently. The older version of the statute banned sexual history evidence with two exceptions. The first exception was for sexual activity involving the defendant and the second was for sexual activity supporting a reasonable mistake defense. ${ }^{122}$ In 1989, perhaps as a reaction to the Hardy case, the statute was revised to pernit an exception only for sexual activity involving the defendant and plausibly supporting his reasonable mistake defense. ${ }^{123}$ Hardy would have a different outcome under the revised version of Georgia's statute since the evidence admitted did not concern sexual activity involving the defendant.

We enter the next Part having encountered various resolutions of the issue of sexual history evidence offered to support a mistake defense. The present state of the law is not only inconsistent, it is also theoretically barren because the courts' decisions have not been adequately supported by theoretical or social justifications. The next Part proposes a solution to further the five pohicies behind the rape shield laws: privacy for victims, increased reporting of rapes, accuracy in rape trials, deterrence, and sexual autonomy. ${ }^{124}$

The proposed solution seeks to resolve the conflict between the mistake of fact defense and the purposes of the rape shield statutes, accoin-

People v. Hooker, 244 Cal. Rptr. 337, 345-46 (1988), officially depublished pursuant to CAL. Cr. R. 976(d)). But cf. People v. Burnham, 176 Cal. App. 3d 1134, 1147, 222 Cal. Rptr. 630, 641 (1986) (court of appeal chose not to follow Hampton, stating: "The mere offer of the defense of consent clearly is not synonymous with substantial evidence of mistake of fact.").

120. Hardy v. State, 159 Ga. App. 854, 857-59, 285 S.E.2d 547, 550-51 (1981).

121. Id. at 858, 285 S.E.2d at 550 (enphasis added). The jurors were "allowed to scrutinize in intimate detail not just the inatter of previous sexual intercourse on the part of the prosecutrix, but her use of birth control, her past dates and boyfriends, and the number and circumstances of her prior sexual experiences." Id. at 858, 285 S.E.2d at 55I. The defendants were acquitted on the rape charge but were convicted of simple battery based on a three-centineter laceration of the attacked woman's vagina, accompanied by profuse vaginal bleeding. Id. at 859-60, 285 S.E.2d at 551-52.

122. GA. CODE ANN. § 24-2-3(b) (Harrison 1981).

123. GA. CODE ANN. § 24-2-3(b) (1990).

124. See supra notes $57-64$ and accompanying text. 
modatimg both the defendant's and the victim's interests. The majority position in the Umited States is that a mistake regarding the woman's consent is a complete defense to rape only if it is both honest and reasonable. ${ }^{125}$ This Comment links the substantive reasonableness requirement to the evidentiary question and argues that a reasonable person infers consent based on communication during the encounter in question, not on knowledge that a woman is sexually experienced. The discussion below seeks to eradicate gender-based discrimination in the judicial system's treatment of sexual history evidence offered to support a mistake defense.

\section{IV}

\section{A Proposal for Reform in the LAW of Rape}

The central question this Comment answers is whether knowledge of a woman's "promiscuity" can contribute to a normatively reasonable mistake as to consent. This requires an inquiry into the role of gender socialization in creating mistakes and a look at alternative methods of sexual commumication that reflect hunian needs rather than sexual stereotypes.

\section{A. Inferring Consent From Sexual Experience Is Normatively Unreasonable}

Many men beheve that sexually experienced women are inore likely than so-called virtuous women to mean "yes" when they say "no" to sex. ${ }^{126}$ This behief is the result of a socialization process that defines women according to standards set by male-dominated imdustries catering exclusively to inen, the most obvious bemg the multi-billion dollar ${ }^{127}$ pornography industry. Most courts have rejected such behiefs about women in the context of consent. In federal courts and in most state courts, evidence of a victim's sexual history is no longer considered relevant on the issue of whether she consented im a particular instance. ${ }^{128}$ Having rejected such behefs in the consent context, the legal system should not reverse itself and legitimize such behiefs by attributing them to

125. See supra text accompanying notes $42-44$. Most commentators agree that strict criminal liability for rape, regardless of reasonable mistake, would be unfair. Steven Katz explains this position:

[S]ome courts have even gone as far as to suggest that there is no mens rea for rape; that, in effect, without a valid consent defense a man is strictly liable for sexual contact which takes place under conditions of foree. Of course this is nonsense. Rape, like all of the other serious crimes against the person, has a mental element, and by and large that element is intent.

Katz, supra note 22, at 48 (footnote omitted).

126. See supra text accompanying notes 50-51.

127. J. Stoltenberg, Refusing To Be A MAN 119 (1989).

128. See supra text accompanying notes $76,86-87$. 
the reasonable person in the context of the reasonable mistake defense. A reasonable person infers consent based on communication froin his partner, not froin the stereotypical expectation that a sexually experienced woman, or any woman for that matter, is available for his gratification.

\section{The Mistake Defense Should Not Enshrine Gender-Biased Assumptions}

Commentators have traced the cause of mistakes in a sexual context to the gap in inale and fernale perceptions of sexuality. ${ }^{129}$ Men are socialized to think of sex as a conquest in which any woinan who can be conquered without overt force is fair play. ${ }^{130}$ Indeed, they may even see physical aggression as seduction, not rape. ${ }^{131}$

Mistake of fact based on the defendant's knowledge of the victim's sexual experience is premised on the inale perception that a woman (especially a bad girl) who says no, in fact, ineans yes. ${ }^{132}$ This perception is unreasonable because it dehunranizes woinen by belitthing the choices they make. It assumes woinen are intrinsically different from men in sexual inatters, rather than recognizing that any differences are the product of inale and feinale socialization.

The widespread incidence of violence against and coercion of women as a ineans of sexual gratification ${ }^{133}$ seems incomprehensible unless one looks to the context that shapes male sexual perceptions in our culture. Recent debate has centered around the role of pornography in socializing inen to accept objectification of and violence against woinen. ${ }^{134}$ Andrea Dworkin calls pornography "the DNA of male dom-

129. See, e.g., Comment, supra note 16, at 147 ("The reasonable person standard assumes a consensus within the population. ... If women and men always communicated their sexual interests and desires in the same inanner, or if they understood each other's coininunications, they could, in fact, be represented by the same hypothetical person. . . . Behavior is not so accurately perceived, however; a gender gap in sexual communications exists."); J. STOLTENBERG, supra note 127, at 9-16 (men and woinen are socialized to look at sex differently).

130. See J. Stoltenberg, supra note 127, at 95 (in a recent survey, $70 \%$ of men found it acceptable to "tell a girl you love her so that you can have sex with her").

131. Comment, supra note 16 , at 147 ; see also Skelton, supra note 24 , at 17 , cols. $2-3$ (in a recent survey, only $39 \%$ of inen denied using force to obtain sex; in a 1987 study, $78 \%$ of feinale college students reported that they had been sexually victimized by male students; a 1991 Stanford study showed that one-third of Stanford's woinen students have had sex when they did not want to). Commentators have discussed the correlation between male violence and pornography's portrayal of woinen as sex objects. See, e.g., A. Dworkin, Pornography: MEN POSSESSing Women (1979) (theoretical study of pornography and violence).

132. Cf. Estrich, supra note 15, at 1093-105 (asserting that a "no ineans yes" philosophy has characterized the comınon law tradition of rape).

133. In America, it is estimated that a woman is raped every three minutes. J. STOLTENBERG, supra note 127 , at 131.

134. See, e.g., TAKe BACK THE Night: Women ON PORNography (L. Lederer ed. 1980) 
ination."135 Studies have shown that the majority of men consider pornography a primcipal source of information about sex. ${ }^{136}$ The primary effect of pornography is to create a perception of sexuality based on inale "violence, dominance, and conquest."137

Pornography's secondary effect has been to make its users perceive sexuality as unclean. Most pornography users are unlikely to claim a connection between love or aesthetic appreciation and the meat-like depictions of women found even in mainstream pornography. ${ }^{138}$ Rather, the words and images in pornography conjure up the image of woman as whore, an image that the male socialization process connects simultaneously with hatred, sexual arousal, and domination. ${ }^{139}$

The reasonable imistake defense should not validate such deleterious

[hereinafter TAKE BACK THE NIGHT] (collection of articles on pornography and violence against women).

135. A. DwORKIN, supra note 131, at xxxix; see also J. STOLTENBERG, supra note 127, at 129 ("[p]ornography institutionalizes male supremacy the way segregation institutionalizes white supreinacy"). In 1983, Minneapolis enacted a law recognizing pornography as a form of sex discrimination. Id. at 163 . The law created a civil rights cause of action against pornographers by people who had been victimized by pornography. Id. at 145. The Minneapohs Civil-Rights Antipornography Ordinance drafted by Andrca Dworkin and Catharine MacKinnon defined pornography as graphic, sexually explicit material actively subordinating women and portraying one of nine scenarios. Id. at 155-58. The scenarios include, for example, showing woinen presented in scenes of degradation, or portraying women as sexual objects, as enjoying humiliation or rape, or as "whores by nature." Id. at 156-58.

136. COMM'N ON OBSCENITy \& Pornography, The Report of the COMmission OF OBSCENITY AND PoRnOGRaphy (1970). Pornography not only informs men abont sex, it also shapes their sexual beliefs and lifestyles. Pornography makes men feel powerful because it portrays perises as weapons and sex as a conquest with the winner judged by his ability to humiliate the object of the conquest. See J. STOLTENBERG, supra note 127, at 134. The debate concerning pornography is complicated by the mability of many people to distinguish between pornography and erotica. See Steinem, Erotica and Pornography: $A$ Clear and Present Difference, in TAKE BACK THE NIGHT, supra note 134, at 35-39. Erotica mvolves "mutually pleasurable, sexual expression between people who have enough power to be there by positive choice," while the message in pornography is "violence, dominance, and conquest." Id. at 37.

137. See J. StOlteNBERG, supra note 127, at 141 (experiments showing the average man was more prone to violence against women after exposure to certain types of pornography); see also Steinein, supra note 136, at 37 (discussing pornography's message of violence, objeetification, and degradation). Pornography not only encourages men to treat women violently but also, as Gloria Steinem makes clear, negatively affects the way women view themselves:

Consider also our spirits that break a little each time we see ourselves in chains or full labial display for the conquering male viewer, brnised or on our knees, screaming a real or pretended paiu to delight the sadist, pretending to enjoy what we really don't enjoy, to be bhind to the images of our sisters that haunt us-humiliated often enough ourselves by the truly obscene idea that sex and the domination of women must be combined.

Id. at 39 .

138. See, e.g., J. STOLTENBERG, supra note 127, at 140 (examples of pornographic depictions of woinen). The June 1978 issue of Hustler magazine, promoted as an "all-meat issue," sliowed a naked woinan pushed head first into a meat grinder coming out at the other end as raw hamburger. Id.

139. See A. Dworkin, supra note 131, at 199-202 (the image of woman as whore is integral to the framework of inale sexual domination); $c f$. J. STOLTENBERG, supra note 127, at 121 (discussing how male sexuality is shaped and defined by pornography: "Pornography tells lies about women. But pornography tells the truth about men."). 
attitudes about female sexuality. Although it may be argued that many men (and women) are socialized to believe that a sexually experienced woman is inore likely to consent to sex, this belief has been rejected in the consent context and should not logically be validated in the mistake context. Validating such a belief is a validation of the depiction of so-called "whores" as unwortlyy of basic human respect. The reasonable person does not rely on stereotypes of sexually experienced women as whores or of men as uncontrollable sex machines.

\section{The Need for a Communicative Model of Sexuality}

An analysis of the mistake defense reveals that it is similar to the consent defense in that botli reflect and perpetuate erroneous views of sexuality. Lois Pineau discusses the two models of sexuality that appear in legal decisionmaking - the "contractual" model and the "communicative" model. ${ }^{140}$ Altlougl Pineau focuses on the consent defense, her analysis applies equally well to the mistake defense.

The traditional approach to consent was based on the contractual model of sexuality. Under this model, a woman's sexually provocative behavior creates an imphed contract where she is required to fulfill her part of the bargain by submitting to supposedly insistent male sexual needs that her conduct created. ${ }^{141}$ Men are not born with the idea that certain kinds of women owe them sex in certain situations. Instead, the traditional contractual model recognizes and validates the male socialization process discussed in the previous Section. It reflects, the genderbiased notion that male sexual needs are somehow inherently different from female sexual needs.

The mistake defense, as currently formulated, is also based on the contractual model of sexuality. A contractual analysis leads to the conclusion that a woman who is sexual witli many men creates the expectation that she will fulfill male sexual needs generated by the knowledge of her sexual encounters. According to the contractual model, it is natural for men to have sucl expectations because of the insistent nature of their sexuality, which contrasts with the gentle and rational nature of fernale sexuality. ${ }^{142}$

The contractual model of sexuality, however, has been rejected in the consent context. We no longer require a woman to resist to the maximum extent possible as proof that she did not want to have sex, or as proof that she did not ask for it. The legal systein seeins to have recognized that nonconsent can be communicated in subtler ways. This recog-

140. Pineau, Date Rape: A Feminist Analysis, 8 LAw \& PhIL. 217, 227-37 (1989).

141. Id. at 227.

142. See id. at 227-28 ("One does not go into the lion's cage and expect not to be eaten. Natural feminine reluctance ... is no protection against a sexually aroused male."). 
nition hints at a new analytical framework-what Pineau calls "communicative" sexuality. ${ }^{143}$ Just as the contractual model has been rejected in the consent context, it should logically be rejected in favor of the communicative model in the mistake context.

A communicative unodel of sexuality in the mistake context requires a mistake to be based on soine verbal (preferably) or nonverbal indication of consent from the woinan, rather than on misguided ideas about male and feinale sexuality. Pineau states the principle as follows:

[I] $t$ seems to me that there is a presumption in favor of the connection between sex and sexual enjoyment, and that if a man wants to be sure that he is not forcing himself on a woman, he has an obligation either to ensure that the enconnter really is mutually enjoyable, or to know the reasons why she would want to continue the encounter in spite of her lack of enjoyment. ${ }^{144}$

Pineau works froin the well-recognized principle that, for both inen and woinen, enjoyable sex requires communication. ${ }^{145}$ As Pineau indicates, it is unreasonable for a man to expect a woinan to agree to sex that is not enjoyable for her. Given the assuinption of mutuality, it follows that a reasonable mistake defense cannot be based solely on a inan's contractual analysis of the situation. That is, a man inay not argue that he knew that the woman was sexually experienced and that this created an expectation of sexual gratification, for which he mistakenly thought she would oblige.

Instead, under the communicative model of sexuality, the reasonable mistake defense would require a man to persuade the jury that he thought the woinan found the activity enjoyable or was willing to engage in it for otlier reasons. Many rape defendants, of course, contend that their victim liked it because she was sexually experienced. This stateinent, however, inust be evaluated according to a realistic notion of what people enjoy, ratlier than being accepted as a bald contractual assertion that her "promiscuity" created an expectation that she would enjoy sex witl anyone.

Consent in a sexual context is not always expressed verbally. Nonverbal siguals, however, must be analyzed in a manner consistent with the communicativc model of sexuality. The inere assertion that "she acted like she wanted it" is not sufficient. Even the defendant's genuine behef does not suffice unless it is grounded in a reakistic notion of why someone would consent to sex.

143. Id. at 233-37.

144. Id. at 234.

145. Id. at 231 (citing the unanimous agreement of sexologists that "mutual sexual enjoyment requires an atmosphere of comfort and communication, a minimum of pressure, and an ongoing check-up on one's partner's state"). 
This is not to say that nonverbal consent is never adequate. When a woman says she does not want to have sex, however, her words should be respected, regardless of the nonverbal signals a man may sense. This is consistent with the law of consent in other situations. For instance, if a panhandler asks for money and is refused, he or she cannot then justify robbery on the grounds of a mistaken behef based on nonverbal signals imdicating the desire to donate. Between nonverbal signals, which are almost inherently ambiguous, and verbal ones, the law must look to the verbal imdicators.

In other situations, the issue of nonverbal consent may be more complex. In an encounter that was not outwardly violent (for example, a date rape situation) and where the victim did not verbally protest, the defendant may claim that the victim's nonverbal siguals led him to beheve she consented. Let us not forget, however, that in order for this situation to arise, there must be a woinan who states that she was raped, who is prosecuting her claim, and who states that she in no way (verbally or nonverbally) consented to sex. Unless the woman's statements are to be considered intrinsically suspect, the defendant's argument of consent based on nonverbal signals seems weak at best. Nevertheless, it would remain for him to persuade the trier of fact that the victim wanted to engage in sex. Similarly, she could offer an explanation, such as fear or mtimidation, for her failure to tell him she did not want to engage in sexual intercourse.

Sexual experience, of course, cannot be considered a nonverbal coinmunication of any kind to a defendant. As discussed, a reasonable person bases his behief in consent on what transpires during the encounter, not on a contractual analysis of the situation. Thus, the communicative model justifies and requires exclusion of sexual history evidence.

Apart from being theoretically compelled, this conclusion is consistent with the basic goals of the criminal law. The law cannot provide retribution if it exonerates an attacker based on the victim's sexual history, and, as if that were not enough, makes the victim's sexuality an issue im open court. Nor can we satisfy the public safety goal behind criminal law if we refuse to convict men of rape because they believe that sexually experienced women are available. Finally, criminal law's function of shaping society's beliefs, imvoked in the rape shield context, is also relevant $m$ the nnistake context. Pumshing men who force sex on a woman based on their oppressive beliefs sends a strong message that acting on these beliefs will not be tolerated.

\section{The Implications of Substantive Reform on the Law of Evidence: Sexual History Evidence Is Irrelevant}

Banning evidence that a rape victim is sexually experienced is 
proper because knowledge that a woman is sexually experienced cannot contribute to a reasonable belief in consent. ${ }^{146}$ The communicative model of sexuality requires a manifestation of consent during the encounter in question. ${ }^{147}$ Sexual history evidence is irrelevant because it cannot substitute for communication. Since a defendant has no constitutional right to present irrelevant evidence, ${ }^{148}$ such evidence may be excluded under the rule of the apphicable jurisdiction banning irrelevant evidence. Commentators have advanced a similar rationale for excluding evidence of sexual experience offered to show consent. ${ }^{149}$ Consistency and fairness demand that this rationale be extended to the constitutional analysis of mistake.

As previously mentioned, sexual history evidence may be subdivided into three categories: reputation, opinion, and specific acts evidence. ${ }^{150}$ Reputation and opinion evidence are considered less probative tlian evidence of specific instances of conduct. ${ }^{151}$ Under a communicative model of sexuality, reputation or opinion evidence that the victim was sexually experienced can never be admissible to show the defendant's inistaken belief in consent. As discussed, the communicative model requires coinmunication between the two people during the encounter, rather than rehance on stereotypical notions of sexuality.

A witness' opinion regarding the victinı's sexuality cannot substitute for communication, even where the evidence does not slow mere proiniscuity but demonstrates a specific type of conduct. Hence, $m$ an encounter imvolving "rouglı sex," a witness' testimony that, in his opinion, the

146. As with sexual history evidence offered to prove consent, evidence offered to prove mistake does not magically acquire relevance where it is offered in tandem with other evidence. "I thought she consented because I knew she was promiscuous" is not validated by the existence of other factors such as nonresistance. However, offering evideuce of sexual conduct to prove a pattern of sexual behavior raises a separate question. See infra notes $165-67$ and accompanying text.

147. For a discnssion of the communicative inodel, see supra text accompanying note 144.

148. See, e.g., Doe v. United States, 666 F.2d 43, 47 (4th Cir. 1981) (justification for excluding reputation aud opinion evidence offered to show consent is that the defendant has no constitutional right to present irrelevant evidence).

149. See Privacy of Rape Victims, supra note 58, at 55 (written testimony of Professor Laurence Tribe concerning the constitutionality of Federal Rule of Evidence 412: "Nothing in the proposed amendment to the Federal Rules of Evidence would override the defendant's due process right in extraordinary circumstances to adduce crucial evidence of innocence; ouly the occasional loss of marginally relevant evidence can plausibly be attributed to the amendinent, and that seems an eminently reasonable price to pay for an important humanization of the trial process in cases where the charge is rape.").

150. See supra text accompanying note 47.

151. See Kneedler, supra note 49, at 489-91, 500-01 (reputation evidence has hittle probative value and is highly prejudicial, although evidence showing a distinctive pattern in consensual sexual conduct may be deemed relevant); see also Privacy of Rape Victims, supra note 58, at 16 (testimony of Roger Pauley, Department of Justice, that reputation and opinion evidence are "the weakest forns of evidence" and that eliminating them does not pose constitutional problems in light of their low probative value). Rule 412 bans reputation and opinion evidence. FED. R. Evid. 412(a). 
woman enjoyed rough sex would be irrelevant. Evidence of the woman's reputation for enjoying rough sex would also be irrelevant. ${ }^{152} \mathrm{~A}$ reasonable person must ascertain whether his would-be sexual partner is willing to be touched in a certain way at a certaim time before he takes affirmative steps towards physically touching her. Reliance on the woman's reputation for past sexual behavior, or on a third party's opimion as to the woinan's sexual experience, without more, reflects the contractual imindset and cannot be attributed to the reasonable person. ${ }^{153}$ The victim's reputation for a specific type of sexual behavior does not imply that she loses her legal ability to say no to the same behavior in the future. Thus, we are left with specific sexual acts as the only evidence that might possibly be admissible under the commumicative model.

\section{B. Exceptions to the Rule: When Is Sexual History Evidence Relevant and Admissible?}

This Comment has argued that generally a rape defendant's knowledge of the victim's sexual experience is irrelevant to a mistaken belief in consent which could be termed reasonable. There may, however, be situations where, consistent with the commuricative inodel of sexuality, sexual history evidence could be relevant. These situations fall into two categories. First, the situations may involve prior sexual activity with the defendant. Many rape shield statutes do not ban this type of evidence. Second, they may involve sexual activity with persons other than the defendant, evidence of which, although generally not admissible under the terms of the rape shield statutes, is adimssible if constitutionally required. ${ }^{154}$

\section{Past Sexual Experience With the Defendant: The Interplay of the Communicative Model With Rule 412(b)(2)(B)}

Evidence of the victim's past sexual acts with the defendant offered to show consent is excepted froin Rule 412's ban on sexual history evidence. ${ }^{155}$ This, of course, is not a per se rule of adınissibility. The evidence inust still be relevant and inust not be unfairly prejudicial. ${ }^{156}$

Rule 412(b)(2)(B)'s exception for evidence of prior sexual conduct

152. Even specific instances of conduct showing consensual rough sex would be irrelevant, absent an attempt to show that there was an affirmative manifestation of consent during the encounter (thus satisfying the commumicativc model).

153. This is true no matter how specific the evidence about the woman's sexual character. In other words, a woman's reputation for hiking whips, although admittedly more specific than a reputation for "promiscuity," would still be inadmissible under the cominunicative model. For further discussion, see infra text accompanying note 165 .

154. See, e.g., FED. R. EvID. 412(b)(1).

155. Id. Rule 412(b)(2)(B).

156. Id. Rule $402,403$. 
with the defendant has been criticized by commentators on the grounds that such evidence is no more probative than sexual history evidence im general. ${ }^{157}$ The exception may seem logical when viewed through the lens of the contractual model. ${ }^{158}$ The better view, under a modern analysis, would use a relevancy test based on the communicative model of sexuality, eschewing stereotypes. Thus, in a consent context, the evidence cannot be found relevant merely on the theory that a woman who consents once with the defendant has a propensity to consent with him.

Evidence of prior consensual sex with the defendant could also be offered in the mistake context. As in the consent context, an analysis of such evidence must be guided not by the contractual ${ }^{159}$ but by the commumicative model of sexuality. A communicative analysis attempts to understand the specifics of the encounter. It requires a manifestation of consent by the woman to the encounter in question. Thus, the mere fact that the woman previously consented to sex with the defendant is not relevant to the mistake defense under the communicative model of sexuahty. Feelings and situations are not static; a prior yes cannot be mentally regurgitated by the defendant whenever he desires sex.

Excluding evidence of prior consensual sex with the defendant is consistent with the five pohicies behind rape shield statutes. ${ }^{160}$ First, the victun's privacy would be protected because her past sex life with the defendant would not become the subject of a courtroom discussion. As a result, she would be more likely to report the rape, furthering the second pohicy. Third, accuracy in rape trials would improve because jurors would look not to the woman's past, but to the specifics of the encounter, to determine if there was a rape. Fourth, deterrence would be advanced by sending a message that past lovers are not fair game for rape. Finally, protecting a woman from rape regardless of her past relationship with the rapist would preserve a woman's sexual autonomy. Thus, a woman's choice to engage in consensual sex would not jeopardize her legal reinedy if her sexual partner later assaults her. A woman's right to terminate a sexual relationship would be recognized and vahiated.

Nouetheless, evidence of past sexual acts with the defendant may be relevant to understanding the defendant's basis for concluding that the

157. See Katz, supra note 22 , at 43 (evidence of past sexual condnct with the accused is probative only under the assnmption that men expect continued sexual access).

158. A contractual understanding of Federal Rule of Evidence 412(b)(2)(B) would consider it reasonable for a man to expect a woman to consent to sex with him because she had consented in the past. An exccilent example of this sort of thinking is the common law treatinent of marital rape. The common law regarded marriage as a contractual relationship in which the woman had effectively signed away her right to withhold consent to sex with her husband. See id. at 28.

159. See supra text accompanying notes 140-43. John Stoltenberg satirizes this contractual analysis: "[I]f she ever said yes once-yes oncc on a date, yes once three years ago, yes once just oncc: a yes to any penis is permanent ...." J. STOLTENBERG, supra note 127, at 178.

160. See supra notes 57-64 and accompanying text. 
woman consented to sex. He may have behieved she consented because of signals they traditionally used during their sexual encounters. A juror unfamiliar with the mechanics of the relationship might consider these signals ambignous. The task of determining when such evidence might be relevant is similar to the task of determining when evidence of specific conduct with other defendants might be relevant. Hence, the two will be treated together in the Subsection below.

\section{Sexual History Evidence With Persons Other Than the Defendant}

The federal Constitution may require that a rape defendant be permitted to introduce evidence of the victim's sexual history to support a mistake defense if the evidence is relevant. ${ }^{161}$ This Coinınent has discussed how evidence offered to show that the victim was sexually experienced is irrelevant to a reasonable mistake defense and inay be constitutionally excluded. ${ }^{162}$ The inquiry becomes what type of sexual history evidence might be relevant, and thus possibly constitutionally required. ${ }^{163}$

In certain limited situations, specific instances of sexual conduct could be relevant to establish mistake. We have seen how prior sexual activity with the defendant may be relevant to a reasonable mistake defense ouly where the defendant first persuades the court that there was a manifestation of consent in the particular situation. This is no easy task. No case would arise unless the victim came to court claiming nonconsensual sex. Thus, the defendant must show, independently of the sexual history evidence, some grounds for interpreting the woinan's behavior at the time of the sexual encounter in question as a inanifestation of consent. Only then will sexual history evidence becoine relevant.

Professor Harriet Galvin offers a hypothetical exanıle where prior sexual experience could be offered to support a mistake defense:

161. See, e.g. Berger, supra note 42, at 63 ("[E]vidence that the accused had reason to think [the victim] willing because of her prior sexual conduct could be crucial to the defendant's case. Moreover, since the victim's history or reputation is only relevant insofar as the accused knew of it at the time, allowing such proof to evince mistake wonld not entirely loose the floodgates. . . . Due process demands that a person charged with crime be allowed to make out any defense provided him by the substantive law; legislative caution demands no less. Therefore, a wisely drafted statute will not prohibit proof of the woman's sexual history offered to show the defendant's honest (reasonable) behef that she yielded to him voluntarily.") (footnotes omitted).

162. See supra Section IV(A)(1).

163. Professor Estrich appears unimpressed by rape defendants wishing to present sexual history evidence to show imistake. See Estrich, supra note 15, at $1100 \mathrm{n} .26$ ("It is not clear why framing the issue in terms of consent-rather than the defendant's knowledge or intent with respect to consent-could constitutionally provide a woman victim with any more protection of her sexual history."). Estrich's analysis suggests that, whether the focus is on the victim's consent or the defendant's state of mind, the scope of the defendant's sixth amendinent right is the same. Thus, the defendant would have no greater right to present sexual history evidence to show mistake than he would to show consent. 
Imagine a case . . . in which the defendant had been told that the coinplainant is "turned on" by aggressive men and that her "no" really ineans "yes." Assume further ... that the encounter starts out consensually-an agreed-upon dinner date or car ride-and culminates in sexual intercourse. . . . In such a case, the defendant may couple his conseut defense with a claim that he reasonably believed the complainant consented. ... [If] there is no independent evidence of rape, arguably the defendant should be permitted to offer evidence of her past sexual behavior or of her reputation for particular sexual conduct that he both knew about and rehied upon in forming his belief in her conseut. ${ }^{164}$

Consider which model of sexuality would permit the introduction of the evidencc presented in Galvin's hypothetical. Under the communicative model, some indications of the woman's desire to engage im sex with this defendant at that particular time are required. On Galvin's facts, any analysis that would admit the evidence seems contractually based: I heard that she liked aggressive men; thus I expected her to consent when I came on strong. This is, im substance, no different from using the victim's reputation for being sexually experienced to show an expectation that she would again consent. Under the communicative model, this evidence would not be relevant.

The question becomes that of a logical nexus between the past sexual behavior sought to be introduced and the behavior that culminated in the rape charge. The specific instances of conduct offered as evidence, coupled with the situation in question, must be part of the woman's communication of consent to sexual intercourse, grounded in a realistic notion of why the woman would consent. For example, specific instances where the victim enjoyed rough sex cannot be said to deny her the legal right to say no to rough sex in the future. ${ }^{165}$ There may be reasons why she would consent to rough sex at a certain time or with a certain person but withhold consent to the same type of behavior at a later time.

By contrast, prior activity could be relevant to show whether the woman's particular behavior constituted a communication of consent. For example, if the defendant seeks to show that certain gestures or actions led him mistakenly to beheve in nonverbal consent, evidence that such actions constituted consent in prior encounters could be relevant under the communicative model, if the woman's behavior was equivocal. The same nay be true of verbal communications by the victim to the defendant that could, without some understanding of past communicative behavior between the defendant and victim, be construed as anbiguous or even as a negative response.

164. Galvin, Shielding Rape Victims in the State and Federal Courts: A Proposal for the Second Decade, 70 MINN. L. REV. 763, 850 (1986) (emphasis added) (footnote omitted).

165. Cf. In re Nichols, 2 Kan. App. 2d 431, 436, 580 P.2d 1370, 1375 (1978) (victim's prior consensual sex with defendant did not imply she would consent to intercourse with all his friends). 
To illustrate, suppose the defendant's story is that, after a date, the victim invited him to her hoine and poured hiln a glass of wine. $\mathrm{He}$ argues that he beheved, reasonably, that this was a manifestation of consent to sexual intercourse. Inferring consent froin these equivocal actions does not seein consistent with the communicative inodel of sexuality. To support his theory, however, imagine the defendant offers the victim's past lovers as witnesses. These witnesses testify that the victim frequently preceded consensual sexual encounters by inviting a inan to her honie and offering him wine. Further, they testify that they told the defendant this to prepare him for his ineeting with her.

If not cautiously analyzed, this situation may becoine a back door entrance for sexual history evidence. The evidence, although possibly relevant, has low probative value where the actions (invitation and wine), standing alone, would not be enough to ineet the communicative model's inanifestation-of-consent test. Conversely, the potential for unfair prejudice is high. Jurors may use the evidence for a contractual analysis of the situation notwithstanding limiting instructions. Therefore, evidence of this type should renıan inadmissible. ${ }^{166}$

Another use of sexual history evidence may be to counteract the assumption that the victim would not consent to a certain type of sex. This could be relevant im a mistake context. For example, a defendant im a case involving the rape of another man inay seek to introduce evidence of the victim's consensual gay encounters to counteract the jurors' assumptions that a man would not consent to gay sex. This situation should also be analyzed according to the communicative model. Knowledge of past consensual gay sex alone is not sufficient to estabhish a reasonable behief in consent. ${ }^{167}$ There must be evidence during the encounter in question which reasonably led to a behief in consent. The evidence would becoine relevant ouly if it were combined with some of the factors discussed above, such as prior activity demonstrating particu-

166. The only exception for admitting evidence of this type would be if there were special circumstances giving the evidence higher probative value. Consider, for example, the following hypothetical based on similar facts. Assuine that this was the defendant's seventh date with the victim. On the first and third dates, the victim did not invite the defendant into her hoine. On the fourth date the victim invited the defendant into her hoine but did not offer the defendant a drink. On these three occasions, the two did not have sex. On the other four occasions, the victim invited the defendant up and offered him a drink. On all four occasions, this behavior preceded sexual intercourse, which the victim admits was consensual. Here there is a perfect correlation betwecn the victim's communicative behavior and consensual sex, except for the seventh date. Further, the evidence more obviously relates to communication between the defendant and the victim than does pre-date gossip between a former lover and the defendant about the victim. The case for admissibility here is stronger than in the hypothetical in the text.

167. See McGill v. Duckworth, 726 F. Supp. 1144, 1147 (N.D. Ind. 1989) (proper to exclude evidence of victim's prior consensual homosexual acts in hoinosexual rape case). 
lar communicative behavior or special circumstances giving the evidence higher probative value.

In sum, we have seen that the communicative model must be apphed in any situation involving the admissibility of sexual history evidence to avoid a return to the contractual, deleterious values reffected in the traditional legal treatinent of rape. Applying the principles described in the preceding Sections, much of this analysis may be done situation by situation. A framework for a communicative analysis of sexual situations will steer the legal system away from its past mistakes. A genuine effort on the part of the legal system to understand the principles behind communicative sex is the best protection for rape victims in the 1990s and beyond.

\section{CONCLUSION}

This Comment has addressed the problem of admitting evidence of a rape victim's past sexual behavior to support a defense of mistaken behef in consent. The resolution of this evidentiary question has required addressing issues of gender bias in the administration of rape laws.

This Comment has defined what is reasonable in the context of a mistaken behef in consent. It has criticized male sexual expectations based on gender socialization. A mistake caused by the nuale myth that sexually experienced women are available is unreasonable because it abrogates the rights of women by assuming that women cannot seriously voice sexual choices, while men can. Such beliefs about women were not only wrong fron the beginning, but they have also now been rejected by most of the legal nistitutions that once fostered then. Thus, this Comment has argued that evidence attesting generally to a rape victim's sexual experience is irrelevant to the defense of reasonable mistake because it is unreasonable to assume a woinan consents to sex simply based on lier past consensual encounters.

This Comment has provided guidelines for sexual history evidence supporting a mistake defense to be admitted im limited situations. Evidence of specific instances of sexual conduct may be relevant to a defense of reasonable mistake where, coinbined with manifestations of consent during the encounter, the evidence could lead a reasonable person mistakenly to beheve in consent under a communicative as opposed to a contractual model of sexuahty. Contrary to the Doe court's assertion, the rationale for admitting certain sexual history evidence is not that Congress intended its ban on sexual history evidence to apply only when the evidence was offered on the issue of consent. Rather, relevant evidence may be introduced in situations where the Constitution coinpels its admission because a criminal defendant's right to present exculpatory factors overrides rape shield statutes enacted by Congress or state 
legislatures. Even if the sexual history evidence is relevant, however, rules prohibiting evidence that is more prejudicial than probative may require its exclusion. This Comment does not attempt to hist every situation where sexual history evidence could be admissible, nor does it provide a inodel statute. Its approach, rather, has been to lay out a framework for analyzing each situation as it arises.

The solution proposed here attempts to balance the constitutional rights of criminal defendants against the rights of rape victimis. The goal is to give courts faced with this evidentiary dilemma an alternative to the Doe analysis. Doe could lead us dangerously back to the timies when rape victims, rather than their attackers, were placed on trial. Doe's unlimited admission of sexual history evidence whenever a defendant raises the mistake defense undoes the progress of the last twenty years. Doe must be stopped in its tracks, and only a solution that strikes a balance between both sides of the debate has a realistic chance of working in theory and principle. I hope, for the sake of future rape victims, that this Comment has found that solution. 